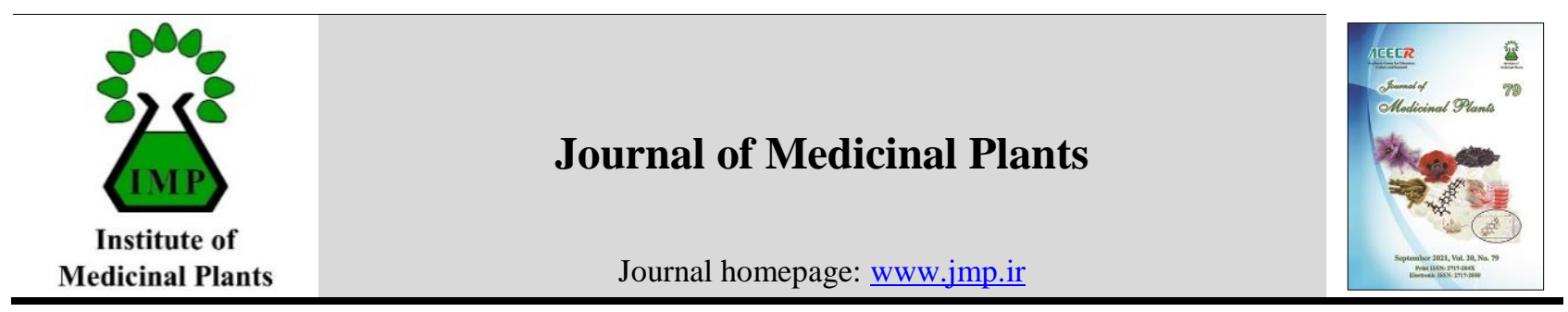

Research Article

\title{
Identification of isoflavonoids in antioxidant effective fraction of Arum rupicola Boiss. leaves
}

\section{Zahra Tofighi ${ }^{1,2}$, Yasaman Shahpar ${ }^{2}$, Alireza Taheri ${ }^{3}$, Saeed Tavakoli ${ }^{4}$, Raymond Asatouri, Mahdieh Eftekhari ${ }^{6}$, Mahdi Vazirian², Mohammad Reza Shams Ardekani ${ }^{2}$, Seyede Nargess Sadati lamardi ${ }^{7}$,*}

${ }^{I}$ Medicinal Plants Research Center, Faculty of Pharmacy, Tehran University of Medical Sciences, Tehran, Iran

${ }^{2}$ Department of Pharmacognosy, Faculty of Pharmacy, Tehran University of Medical Sciences, Tehran, Iran

${ }^{3}$ Department of Medicinal Chemistry, Pharmaceutical Branch Islamic Azad University, Tehran, Iran

${ }^{4}$ Medicinal Plants Research Center, Institute of Medicinal Plants, ACECR, Karaj, Iran

${ }^{5}$ Department of Biology, Science and Research Branch Islamic Azad University, Tehran, Iran

${ }^{6}$ Department of Pharmacognosy and Pharmaceutical Biology, Faculty of Pharmacy, Kermanshah University of Medical Sciences, Kermanshah, Iran

${ }^{7}$ Department of Traditional Pharmacy, School of Persian Medicine, Tehran University of Medical Sciences, Tehran, Iran

\begin{tabular}{|c|c|}
\hline ARTICLE INFO & ABSTRACT \\
\hline $\begin{array}{l}\text { Keywords: } \\
\text { Arum rupicola } \\
\text { Antioxidant } \\
\text { Cytotoxic effect } \\
\text { Genistein } \\
\text { Isoflavonoid }\end{array}$ & $\begin{array}{l}\text { Background: Arum rupicola Boiss. (Araceae Family) is used by the native people of } \\
\text { southern areas of Iran as a soup called "kardeh soup". Several flavonoids and phenol } \\
\text { compounds have been identified from Arum species. Objective: The aim of this study was } \\
\text { to evaluate antioxidant effect and total phenol contents as well as cytotoxic activity of the } \\
\text { leaves of A. rupicola. Methods: Antioxidant activity of total methanol extract and fractions } \\
\text { including } n \text {-hexane, chloroform, ethyl acetate and water residue were evaluated using FRAP } \\
\text { and DPPH methods. Total phenol content was measured using Folin-Ciocalteu method. } \\
\text { Cytotoxic activity of the extract and fractions were investigated against human breast cancer } \\
\text { MCF-7, MDA-MB-231, and T47D cell lines by MTT assay. Further phytochemical } \\
\text { isolation was done on the water residue using column chromatography. Results: According } \\
\text { to the results, water residue showed the lowest } \mathrm{IC}_{50} \text { value }(186.7 \mu \text { g/ml) and the total } \\
\text { methanol extract showed the most antioxidant power (163.62 mmol FeSO4/100 g extract) } \\
\text { and phenol content ( } 135 \mu \text { mol Gallic acid/g extract). The hexane fraction also showed the } \\
\text { highest cytotoxic effect against MCF-7 breast cancer cell line with } \mathrm{IC}_{50} \text { equal to } 118.9 \mu \mathrm{g} / \mathrm{ml} \text {. } \\
\text { Phytochemical analysis of the water residue resulted in isolation and identification of three } \\
\text { isoflavonoids named orobol, genistein and genistein } 8 \text { - } c \text {-glucoside. Conclusion: Based on } \\
\text { the identification of isoflavonoid compounds in this plant, its ability to be used as a } \\
\text { phytoestrogenic supplement can be considered in future studies. }\end{array}$ \\
\hline
\end{tabular}

Abbreviations: FRAP, Ferric Reducing Ability of Plasma; DPPH, 2,2-Diphenyl-1-picrylhydrazyl; MTT, 3-(4,5Dimethylthiazol-2-yl)-2,5-diphenyl tetrazolium bromide

* Corresponding author: $\underline{n} \_$sadati@tums.ac.ir

doi: $10.52547 /$ jmp.20.79.14

Received 10 March 2021; Received in revised form 18 June 2021; Accepted 3 July 2021

(C) 2020. Open access. This article is distributed under the terms of the Creative Commons Attribution-NonCommercial 4.0 International License (https://creativecommons.org/licenses/by-nc/4.0/) 


\section{Introduction}

Arum is a genus of flowering plants belonging to family Araceae, represented by 26 species and distributed in Northern Africa, Mediterranean Region, Western Asia, and Europe [1]. Several Arum species are growing in Lebanon, Cyprus, Syria and Palestine and consumed in folk medicine for treatment of cancer, cough, hemorrhoids, worms, constipation and urinary tract infections. The fresh leaves of Arum used in cooked or roasted form after washing several times with salted water [2]. Arum rupicola Boiss (Syn. Arum conophalloides Kotschy ex Schott) is used by the native people of southern areas of Iran as a soup called "kardeh soup" [3]. Also in some areas of Turkey the aerial parts of $A$. rupicola with local name of "kahri" were used as a rice-vegetable dish [4]. Various pharmacological effects of Arum species have been reported such as antioxidant, and antimicrobial effects [5-7]

A variety of flavonoids including, vitexin, caffeic acid, luteolin, vicenin and 3,6,8trimethoxy, 5,7,3',4'-tetrahydroxy flavone [8] and the alkaloid (S)-3,4,5-trihydroxy-1 H-pyrrol2(5H)-one were isolated from A. palaestinum [9]. Also several flavonoids such as apigenin, luteolin, quercetin, vitexin, isoorientin, esculin, quercetin-3-O- $\beta$-glucoside, caffeic acid, and ferulic acid have been identified from A. dioscoridis [10, 11]. Flavonoids have antioxidant, anti-cancer, anti-allergic, antiinflammatory and anti-viral phytochemical compounds [12]. Since several flavonoids and phenolic compounds reported in the genus Arum, it can be expected that the aerial parts of the plant contain interesting biological active metabolites. The aim of this study was to evaluate phytochemicals, antioxidant effect and total phenolic contents of the leaves of Arum rupicola collected from southern areas of Iran.

\section{Materials and Methods}

\subsection{Chemicals}

2,2-Diphenyl 1-picrylhydrazyl (DPPH; Fluka, Switzerland); butylatedhydroxylanizole (BHA), methanol, hexane, chloroform, ethyl acetate (Merck, Germany) were purchased. ${ }^{1} \mathrm{H}$ and ${ }^{13} \mathrm{C}$ NMR spectroscopy of compounds A, B and C were performed in DMSO- $\mathrm{d}_{6}$ on a Bruker Avance DPX 400 spectrometer (Karlsruhe, Germany) [400 MHz, tetramethylsilane (TMS) as internal standard]. Column chromatography (CC) was done by Sephadex LH-20 (lipophilic Sephadex, 25-100 $\mu \mathrm{m}$; Sigma, Dorset, UK) columns.

\subsection{Plant material}

The leaves of Arum rupicola were collected from their growing habitats in Yasuj area, Iran, April 2016. The plant identified by Dr. Farideh Attar. A voucher specimen of the plant (46054 TUH) is deposited in the herbarium of the faculty of Sciences, Tehran University.

\subsection{Extraction}

The leaves of A. rupicola were air dried and grounded in the laboratory, and the obtained powder (1000 g) was extracted five times at room temperature with $80 \%$ methanol for an interval of three days. The aqueous-methanol extract was evaporated under reduced pressure and temperature to obtain a residue of $398.63 \mathrm{~g}$. The total methanol extract was suspended in water and then fractionated using hexane $(21.52 \mathrm{~g})$, chloroform $(3.03 \mathrm{~g})$, and ethyl acetate $(1.67 \mathrm{~g})$ according to their polarity also water residue was 160.14 g. The excessive solvents were evaporated with a rotary vacuum evaporator (60 rpm at $40{ }^{\circ} \mathrm{C}$ ). All extracts were stored at $4{ }^{\circ} \mathrm{C}$ until use. 


\subsection{Total phenol contents assay}

Total Phenol was determined colorimetrically using Folin-Ciocalteu reagent as described by Velioglu et al. 1998 and according to previous study [13]. The experiments were repeated three times. The phenol content calibration curves were plotted by measuring the absorption of certain concentraitions $(25-150 \mathrm{mg} / \mathrm{L})$ of gallic acid as a standard and the results were expressed as milligrams of gallic acid equivalents (GAE) per gram of dry matter (total extracts and fractions) as means \pm SEM [13].

\subsection{Antioxidant determination of DPPH assay}

The total methanol extract was evaluated for its free radical scavenging activities using 2,2diphenyl-1-picryl-hydrazyl (DPPH) method according to Brand Williams et al. (1995) [14]. Different concentrations $(25,50,100 \mu \mathrm{g} / \mathrm{ml})$ of sample solutions $(1 \mathrm{ml})$ in methanol were added to DPPH methanol solution ( $2 \mathrm{ml}, 40 \mu \mathrm{g} / \mathrm{ml})$. Butylated hydroxyanisole (BHA) $(100 \mu \mathrm{g} / \mathrm{ml})$ was used as positive control. After $30 \mathrm{~min}$, the absorbance was measured at $517 \mathrm{~nm}$. All tests were carried out in triple replicate. Percentage of radical scavenging activity of sample was calculated according to the following equation: Inhibition $\%=[(\mathrm{A} 0-\mathrm{As}) / \mathrm{A} 0] \times 100$ that $\mathrm{A} 0$ is the absorbance of the control and as is the absorbance of the sample. Half maximal inhibitory concentration $\left(\mathrm{IC}_{50}\right)$ value (indicate the concentration of the sample $(\mathrm{mg} / \mathrm{ml})$, required to scavenge $50 \%$ of DPPH) was calculated from the plotted graph of scavenging activity versus the concentration of extract, using linear regression analysis.

\subsection{FRAP assay}

Ferric reducing antioxidant power assay is based on reduction of a ferric-tripyridyl triazine complex to its ferrous colored form in the presence of antioxidants and was performed according to previous studies [15].

\subsection{Cell culture}

Human breast cancer cell lines including MCF-7 (human breast cancer cell line with estrogen, progesterone and glucocorticoid receptors), T47D (breast ductal carcinoma), and MDA-MB-231 (human breast adenocarcinoma), were supplied from the National Cell Bank of Iran Pasteur Institute, Tehran, Iran. Cancer cell lines were developed in RPMI-1640 medium accompanied with $10 \%$ heat-inactivated fetal calf serum, $100 \mu \mathrm{g} / \mathrm{ml}$ streptomycin and 100 $\mathrm{U} / \mathrm{ml}$ penicillin at $37{ }^{\circ} \mathrm{C}$ in a humidified atmosphere with $5 \% \mathrm{CO}_{2}$.

\subsection{Determination of cell viability by MTT assay}

The in-vitro cytotoxic activity of all samples were assessed against three human breast cancer cell lines including MCF-7, T47D, and MDAMB- 231 cell lines using MTT colorimetric assay according to previous work [16].

Concisely, the concentration of 50, 100, 200, 400 and $500 \mu \mathrm{g} / \mathrm{ml}$ from all samples were prepared for each cell line. At first, samples were dissolved in DMSO (Dimethyl Sulfoxide) and further diluted with cell culture medium. The final DMSO concentration used was $0.1 \%$ of total volume of the medium in all treatments, including the control group. In each plate, there were three control wells (cells without test extracts) and three blank wells (the medium with $0.1 \%$ DMSO) for cell viability. Etoposide was used as a positive control for cytotoxicity. The plates were incubated for $72 \mathrm{~h}$. At the end of the incubation period, the medium was removed and $200 \mu \mathrm{l}$ phenol red free medium containing MTT ( $1 \mathrm{mg} / \mathrm{ml})$, was added to wells, and followed by $4 \mathrm{~h}$ incubation. After incubation, the culture medium was then exchanged with $100 \mu \mathrm{l}$ of 
DMSO and the absorbance of each well was measured by using a micro plate reader at 492 $\mathrm{nm}$. For each sample, the concentration causing $50 \%$ cell growth inhibition $\left(\mathrm{IC}_{50}\right)$ compared with the control was calculated from concentration response curves by regression analysis [16].

\subsection{Purification and isolation of flavonoid compounds}

In order to identify the main compounds in the plant, water residue was selected for purification due to proper weight and antioxidant effects. Fifteen grams of the water residue were loaded on a Sephadex LH-20 $(25 \times 5 \mathrm{~cm})$ column and eluted with aqueous methanol $(80 \%)$. Fractions with a volume of $30 \mathrm{ml}$ were collected from this column. The obtained fractions were compared using TLC method and the same fractions were combined. To gain more weight for each fraction, this step was performed several times, each time with about $5 \mathrm{~g}$ of water residue, and the same fractions were combined to afford 4 fractions. Compound $\mathbf{B}$ was isolated from the second column and for the final purification, Sephadex LH-20 column $(80 \times 1 \mathrm{~cm})$ was used. The weight of compound $\mathbf{B}$ was about $20 \mathrm{mg}$. The $\mathrm{R}_{\mathrm{f}}$ of compound $\mathbf{B}$ with the solvent system of formic acid/ acetic acid/water/ethyl acetate $(11 / 11 / 26 / 100)$ on TLC sillicagel $60 \mathrm{~F}_{254}$ was about 0.7 .

To separate compound A, the fractions No. 24-27 of the first column, the fractions 20-23 of the second column and the fractions 31-34 of the third column were combined, and first was loaded on the Sephadex LH-20 $(70 \times 2 \mathrm{~cm})$ column and washed with aqueous methanol (80 $\%)$. Then, the fraction No. 17-24 of this column was dried and for final purification, it was loaded on a Sephadex LH-20 $(80 \times 1 \mathrm{~cm})$ column eluted with methanol (100\%) to afford compound $\mathbf{A}$ (30 mg). The Rf of compound A with the solvent system of formic acid/ acetic acid/water/ethyl acetate $(11 / 11 / 26 / 100)$ on TLC sillicagel $60 \mathrm{~F}_{254}$ was about 0.8 . To separate compound $\mathbf{C}$, the fractions No. 35-37 of the first column, the fractions 28-33 of the second column and the fractions 37-39 of the third column were merged, and then was loaded twice on a Sephadex LH-20 $(80 \times 1 \mathrm{~cm})$ column eluted with methanol $(100 \%)$ to afford compound $\mathbf{C}(3 \mathrm{mg})$. The $\mathrm{R}_{\mathrm{f}}$ of compound $\mathbf{C}$ with the solvent system of formic acid/ acetic acid/water/ethyl acetate (11/11/26/100) on TLC sillicagel $60 \mathrm{~F}_{254}$ was about 0.6.

\subsection{Chemical analysis}

${ }^{1} \mathrm{H}$ and ${ }^{13} \mathrm{C}$-NMR spectroscopy of compounds A, $\mathbf{B}$ and $\mathbf{C}$ were recorded on a Brucker Avance 500 DRX $(500 \mathrm{MHz})$ spectrometer. Chemical shifts are given in (ppm) DMSO using TMS as internal standard. Column chromatography (CC) was performed using Sephadex LH-20 (lipophilic Sephadex, 25-100 $\mu \mathrm{m}$; Sigma, Dorset, UK) columns.

Compound A (Orobol): $\mathrm{C}_{15} \mathrm{H}_{10} \mathrm{O}_{6} \cdot{ }^{1} \mathrm{H}-\mathrm{NMR}$ (400 MHz, DMSO-d $\left.\mathrm{d}_{6}\right): \delta=8.47(1 \mathrm{H}, s, \mathrm{H}-2)$, $7.34\left(2 \mathrm{H}, m, \mathrm{H}-5^{\prime}, 6^{\prime}\right), 6.83(1 \mathrm{H}, d, J=7.6 \mathrm{~Hz}, \mathrm{H}-$ 2'), $6.54(1 \mathrm{H}, s, \mathrm{H}-8), 6.37(1 \mathrm{H}, s, \mathrm{H}-6)$

Compound B (Genistein): $\mathrm{C}_{15} \mathrm{H}_{10} \mathrm{O}_{5},{ }^{1} \mathrm{H}-$ NMR (400 MHz, DMSO-d 6 ): $\delta=8.07(1 \mathrm{H}, s, \mathrm{H}-$ 2), $7.77(2 \mathrm{H}, d, J=7.2 \mathrm{~Hz}, \mathrm{H}-2$ ' , 6') $6.8(2 \mathrm{H}, d$, $J=7.2 \mathrm{~Hz}, \mathrm{H}-3$ ', 5'), 6.57 (1H, $s, \mathrm{H}-8), 6.46(1 \mathrm{H}$, $s, \mathrm{H}-6)$

Compound $\mathrm{C}$ (Genistein 8- $\boldsymbol{C}$-glucoside): $\mathrm{C}_{21} \mathrm{H}_{21} \mathrm{O}_{10}$. UV (MeOH, $\left.\lambda_{\max }, \mathrm{nm}\right): 265 .{ }^{1} \mathrm{H}-\mathrm{NMR}$ (400 MHz, DMSO-d $): \delta=8.00$ (1H, $s, \mathrm{H}-2), 7.93$ $\left(2 \mathrm{H}, d, J=7.2 \mathrm{~Hz}, \mathrm{H}-2^{\prime}, 6^{\prime}\right), 6.88(2 \mathrm{H}, d, J=7.2$ Hz, H-3',5'), 6.59 (1H, $s, \mathrm{H}-6), 4.18(1 \mathrm{H}, d, J=10$ $\mathrm{Hz}, \mathrm{H}-1$ ") 


\subsection{Statistical analyses}

The values were reported as mean \pm SD by SPSS and Excel 2010.

\section{Results}

\subsection{DPPH radical scavenging activity}

Free radical scavenging effects of total extract and different fractions from Arum rupicola leaves were assessed with 2, 2-diphenyl-1-picrylhydrazyl (DPPH). $\mathrm{IC}_{50}$ values were displayed in Table 1.

\subsection{FRAP assay}

Results of antioxidant effects of different fractions of the leaves extract using FRAP, are reported based on mmol Fe II/ $100 \mathrm{~g}$ of extract or fraction. Ferric reducing antioxidant power of the extracts calculated using the calibration curve and regression equation of ferrous sulfate $\left(\mathrm{R}^{2}=\right.$ $0.996, \mathrm{y}=0.0008 \mathrm{x}-0.015)$. According to table 1 , it was presented that antioxidant property of 100 grams of hexane, chloroform, ethyl acetate, and water residue as well as total methanol extract, had antioxidant activity equivalent to $140.17 \pm$ $4.03,140.02 \pm 4.37,110.01 \pm 3.9,108.64 \pm 4.07$ and 163.62 milimol $\mathrm{FeSO}_{4}$, respectively.

\subsection{Total phenol content}

Total phenol content ( $\mu$ mol of $\mathrm{GAE} / \mathrm{g}$ of sample) as represented in table 2 varied from 116.55 to $135.00 \mu \mathrm{mol}$ of $\mathrm{GAE} / \mathrm{g}$ sample using the standard curve of gallic acid $\left(\mathrm{R}^{2}=0.9919, \mathrm{y}\right.$ $=0.0067 \mathrm{x}-0.0194)$.

Table 1. DPPH radical scavenging activity ( $\mathrm{IC}_{50}$ values), total phenolic content (TPC) and antioxidant power (mmol $\mathrm{Fe} / 100 \mathrm{~g}$ sample) of different fractions from Arum rupicola leaves.

\begin{tabular}{cccc}
\hline Sample & IC $_{\mathbf{5 0}}(\boldsymbol{\mu} \mathbf{g} / \mathbf{m l})^{\mathbf{a}}$ & TPC $(\boldsymbol{\mu m o l ~ G a l l i c ~ a c i d / g ~ s a m p l e ~})$ & $\begin{array}{c}\text { Antioxidant power }(\mathbf{m m o l} \\
\text { Fe/100 g sample })\end{array}$ \\
\hline Hexane fraction & $481.5 \pm 2.26^{\mathrm{a}}$ & $120.6 \pm 12.04$ & $140.17 \pm 4.03$ \\
Chloroform fraction & $637.8 \pm 11.3$ & $133.2 \pm 13.5$ & $140.02 \pm 4.37$ \\
Ethyl acetate fraction & $441.2 \pm 4.77$ & $122.4 \pm 12.38$ & $110.01 \pm 3.9$ \\
Water residue & $186.7 \pm 5.8$ & $116.5 \pm 9.7$ & $108.64 \pm 4.07$ \\
Total methanol extract & $467.3 \pm 2.19$ & $135 \pm 11.8$ & $163.62 \pm 4.42$ \\
BHA & $7.9 \pm 0.06$ & - & \\
Vitamin A & $14.2 \pm 1.23$ & - &
\end{tabular}

${ }^{\mathrm{a}} \mathrm{IC}_{50}$ values represent an average of three independent experiments (mean $\pm \mathrm{SD}$ ); BHA: Butylated hydroxyanisole.

\subsection{In vitro cytotoxic assay}

The cytotoxicity analysis of total methanolic extract, hexane, chloroform, ethyl acetate and water residue in breast cancer cell lines including MCF-7, MDA-MB, and T47D cell line was performed and the results were shown in Table 2.

Results showed that in MCF-7 cell line, hexane, chloroform fractions and total methanol extract showed cytotoxicity with $\mathrm{IC}_{50}$ equal to
$118.9 \pm 0.38,258.5 \pm 0.25,392.7 \pm 0.25 \mu \mathrm{g} / \mathrm{ml}$, respectively. In this cell line, etoposide showed cytotoxicity with $\mathrm{IC}_{50}$ of $18.53 \pm 0.24 \mu \mathrm{g} / \mathrm{ml}$.

In the MDA-MB-231 cell line, hexane, chloroform fractions and total methanol extract have shown cytotoxicity with $\mathrm{IC}_{50}$ of $137.2 \pm$ $0.22,239.8 \pm 0.12,357.3 \pm 0.11 \mu \mathrm{g} / \mathrm{ml}$, respectively. Etoposide also showed cytotoxicity with $\mathrm{IC}_{50}$ of $19.9 \pm 0.006 \mu \mathrm{g} / \mathrm{ml}$. 
In the T47D cell line, the fractions of chloroform, hexane, and total methanol extract as well as water residue showed cytotoxicity with $\mathrm{IC}_{50}$ of $113.8 \pm 1.25,122.8 \pm 0.2,249.08 \pm 0.14$, $399.3 \pm 0.6 \mu \mathrm{g} / \mathrm{ml})$, respectively. In this cell line, etoposide showed cytotoxicity with $\mathrm{IC}_{50}$ of $23.3 \pm 0.096 \mu \mathrm{g} / \mathrm{ml}$.

\subsection{Isolation of isoflavonoid compounds}

Isolated compounds $\mathbf{A}, \mathbf{B}$, and $\mathbf{C}$ from the methanolic fraction of the total methanolic extract of leaves of Arum rupicola were identified by comparison of their NMR $\left({ }^{1} \mathrm{H}-\&\right.$ ${ }^{13} \mathrm{C}-\mathrm{NMR}$ ) with those reported in the literatures [17-19]. Compounds A, B and C (Fig. 1) were identified as Orobol, Genistein and Genistein 8C-glucoside, respectively.

Table 2. In vitro cytotoxic activity ( $\mathrm{IC}_{50}, \mu \mathrm{g} / \mathrm{ml}$ ) of total extract and fractions of Arum rupicola leaves against cancer and normal cell lines

\begin{tabular}{cccc}
\hline Sample & $\begin{array}{c}\mathbf{I C}_{\mathbf{5 0}}(\boldsymbol{\mu g} / \mathbf{m l})^{\mathbf{a}} \\
\mathbf{M C F - 7}\end{array}$ & $\begin{array}{c}\mathbf{I C}_{\mathbf{5 0}}(\boldsymbol{\mu} \mathbf{g} / \mathbf{m l}) \\
\text { MDA-MB-231 }\end{array}$ & $\begin{array}{c}\text { IC50 }(\boldsymbol{\mu g} / \mathbf{m l}) \\
\text { T-47D }\end{array}$ \\
\hline Total methanol extract & $392.7 \pm 0.25$ & $357.3 \pm 0.11$ & $249.08 \pm 0.14$ \\
Hexane fraction & $118.9 \pm 0.38$ & $137.2 \pm 0.22$ & $122.8 \pm 0.2$ \\
Chloroform fraction & $258.5 \pm 0.25$ & $239.8 \pm 0.12$ & $113.8 \pm 1.25$ \\
Ethyl acetate fraction & $>500$ & $>500$ & $>500$ \\
Water residue & $>500$ & $>500$ & $399.3 \pm 0.6$ \\
Etoposide & $18.53 \pm 0.24$ & $19.9 \pm 0.006$ & $23.3 \pm 0.096$ \\
\hline
\end{tabular}

${ }^{\mathrm{a}} \mathrm{IC}_{50}$ values represent an average of three independent experiments (mean $\pm \mathrm{SD}$ ).<smiles>O=c1c(-c2ccc(O)c(O)c2)coc2cc(O)cc(O)c12</smiles>

(A)<smiles>O=c1c(-c2ccc(O)cc2)coc2c(C3OC(CO)C(O)C(O)C3O)c(O)cc(O)c12</smiles>

(B)<smiles>O=c1c(-c2ccc(O)cc2)coc2cccc(O)c12</smiles>

Fig. 1. Chemical structure of isoflavonos isolated from Arum rupicola leaves. A: Orobol, B: Genistein, and C: Genistein 8-C-glucoside

\section{Discussion}

Various flavonoids and phenolic compounds have been identified and reported in different species of Arum [20, 21], but no phytochemical studies have been performed on A. rupicola. In this study, antioxidant effects, cytotoxicity as well as purification and identification of secondary metabolites of $A$. rupicola leaves were investigated using different chromatographic and spectroscopic methods.

According to the results, methanolic fraction showed higher radical scavenging effect and the total methanol extract of the plant exhibited higher antioxidant power and total phenol content than other fractions. In a study, antioxidant and antitumor activities of the 
ethanol extracts from different parts of six plants growing in Palestine, including A. palaestinum were evaluated and concluded that the studied plants showed different antioxidant abilities which were strongly associated with their phenolic contents [22].

The results of cytotoxicity study of plant samples on breast cancer cell lines showed that hexane fraction due to more toxicity in breast cancer cell lines could be considered for future studies. One study reported in vitro cytotoxic activity of different fractions and four flavonoid compounds isolated (luteolin, chrysoeriol, isoorientin, isovitexin) from the diethyl ether and ethyl acetate fraction of Arum palaestinum extract were investigated against four human carcinoma cell lines, epidermal carcinoma of larynx (Hep2), cervix (HeLa), liver (HepG2) and breast (MCF-7). Results showed that the fractionated extract and the isolated compounds showed significant antitumor activity against the four cell lines [1].

Phytochemical study of water residue of A. rupicola, using chromatographic methods, led to the isolation and identification of three isoflavonoid compounds, Orobol, Genistein and Genistein 8-C-glucoside. This is the first report on the occurrence of isoflavonoids in the genus Arum. Isoflavones, coumestans, stilbenes, and lignans are important subclasses of phytoestrogens. Isoflavones, which are more studied than other phytoestrogens, have estrogen-like properties in mammals and are found in large quantities in soybean and its products $[23,24]$. Isoflavonoids have also been reported in several plant families in addition to the leguminous family and attracted the attention of many specialists from phytochemistry and plant physiology to medicine and nutrition [25]. Several beneficial effects of isoflavones have been reported, such as cardioprotection, osteoporosis prevention and antioxidant effects, which may be related to their phytoestrogenic effects [26]. Orobol is an isoflavone that is in small amount in soybean and is structurally similar to genistein, a largest isoflavone in soybean. Orobiol and genistein and their derivatives are known as multifunctional isoflavones with biological activities like neuroprotective, antiobesity and anti-cancer [27, 28].

The presence of these isoflavones in A. rupicola can be introduced it as a good source of phytoestrogens and antioxidant.

\section{Conclusion}

According to the results of this study, it can be concluded that the stronger antioxidant effect of water residue of Arum rupicola could be due to the presence of three isoflavonoid compounds called orobol, genistein and genistein 8-Cglucoside. Considering the biological effects of isoflavons, which are a class of phytoestrogens, it is recommended to study the effects of this plant on diseases related to estrogen deficiency and also to expand its use as a food source containing phytoestrogens.

\section{Author contributions}

Substantial contributions to design, analysis and interpretation of data: Z. T., M. V., M. E., and SN. SL; investigation: Y. S., A. T., S. T., and R. A.; drafting the article or revising: Y. S. and SN. SL.; final approval of the version to be published: Z. T. and MR. SA.

\section{Conflict of interest}

We declare that there is no conflict of interest.

\section{Acknowledgment}

This study was supported by Tehran University of Medical Sciences (TUMS) (Grant No: 95-01-56-31529). 


\section{References}

1. Farid MM, Hussein SR, Ibrahim LF, El Desouky MA, Elsayed AM, El Oqlah AA and Saker MM. Cytotoxic activity and phytochemical analysis of Arum palaestinum Boiss. Asian Pac. J. Trop. Biomed. 2015; 5(11): 944-7. doi: 10.1016/j.apjtb.2015.07.019.

2. Jaradat $\mathrm{N}$ and Abualhasan M. Comparison of phytoconstituents, total phenol contents and free radical scavenging capacities between four Arum species from Jerusalem and Bethlehem. Pharm Sci. 2016; 22(2): 120-5.doi: 10.15171/PS.2016. 19.

3. Derakhshanfar A, Moayedi J, Vahedi M and Valizadeh A. Arum conophalloides Aqueous Extract Induced Hepatotoxicity in Rat; Histopathological, Biochemical, and mir-122 Assessments. Microrna. 2020; 9(3): 224-231. doi: 10.2174/ 2211536608666191016142400. PMID: 31622226; PMCID: PMC7366011.

4. Haghighi, H. Essential oil of the aleaves of Arum conophalloides (Araceae) from Iran. IJPS. 2016; 12(3): 11-16. doi: 10.22034/ijps.2016. 23837

5. Farahmandfar R, Kenari RE, Asnaashari M, Shahrampour D and Bakhshandeh T. Bioactive compounds, antioxidant and antimicrobial activities of Arum maculatum leaves extracts as affected by various solvents and extraction methods. Food Sci. Nutr. 2019; 7: 465-475. doi: 10.1002/fsn3.815.

6. Yabalak E. Radical scavenging activity and chemical composition of methanolic extract from Arum dioscoridis SM. var. dioscoridis and determination of its mineral and trace elements. JOTCSA. 2017; 5(1): 205-218. doi: 10.18596/ jotcsa.350370.

7. Al-Shmgani H, Kadri ZHM, Al-Halbosiy MMF and Dewir YH. Phytochemical analysis, cytotoxicity and antioxidant activity of cuckoo pint (Arum maculatum) leaf extract. Acta Biol. (Szeged) 2019; 63(2): 119-124.

8. Afifi FU, Khalil E and Abdalla S. Effect of isoorientin isolated from Arum palaestinum on uterine smooth muscle of rats and guinea pigs. $J$. Ethnopharmacol. 1999 May; 65(2): 173-7. doi: 10.1016/s0378-8741(98)00147-0.

9. El-Desouky SK, Kim KH, Ryu SY, Eweas AF, Gamal-Eldeen AM and Kim YK. A new pyrrole alkaloid isolated from Arum palaestinum Boiss. and its biological activities. Arch. Pharm. Res. 2007 Aug; 30(8): 927-31. doi: 10.1007/ BF02993958.

10. Afifi FU, Kasabri V, Litescu SC and Abaza IM. In vitro and in vivo comparison of the biological activities of two traditionally and widely used Arum species from Jordan: Arum dioscoridis Sibth \& Sm. and Arum palaestinum Boiss. Nat. Prod. Res. 2016 Aug; 30(16): 177786. doi: 10.1080/ 14786419.2015.1072713.

11. Karahan F, Kulak M, Urlu E, Gozuacik HG, Boyumez T, Sekeroglu N and Doganturk IH. Total phenolic content, ferric reducing and DPPH scavenging activity of Arum dioscoridis. Nat. Prod. Res. 2015; 29(17): 1678-83. doi: 10.1080/ 14786419.2014.991320.

12. Panche AN, Diwan AD, Chandra SR. Flavonoids: an overview. J. Nutr. Sci. 2016 Dec 29; 5:e47. doi: 10.1017/jns.2016.41. PMID: 28620474 ; PMCID: PMC5465813.

13. Velioglu Y, Mazza G, Gao L and Oomah B. Antioxidant activity and total phenolics in selected fruits, vegetables, and grain products. $J$. Agric. Food Chem. 1998; 46(10): 4113-7. doi: 10.1021/jf9801973. 
14. Tofighi Z, Es-haghi A, Asl MM, Tajic AR, Navai MS, Tavakoli S, Hadjiakhoondi A and Yassa N. Investigation of chemical keys for relationship between plants and their unifloral honeys by hydrodistillation and SPME and biological activities of honeys. Eur. Food Res. Tech. 2014; 238(4): 665-73. doi: 10.1007/ s00217-013-2147-y.

15. Sadati N, Khanavi M, Mahrokh A, Nabavi S, Sohrabipour $\mathbf{J}$ and Hadjiakhoondi A. Comparison of antioxidant activity and total phenolic contents of some persian gulf marine algae. J. Med. Plants 2011; 1(37): 73-9. Available from: https:// www.sid.ir/en/journal/ ViewPaper.aspx?id=200886.

16. Alipour E, Mousavi Z, Safaei Z, Pordeli M, Safavi M, Firoozpour L, Mohammadhosseini N, Saeedi M, Ardestani SK and Shafiee A. Synthesis and cytotoxic evaluation of some new [1,3] dioxolo [4,5-g] chromen-8-one derivatives. DARU. 2014; 22(1): 41. doi: 10.1186/20082231-22-41.

17. Al-Mahweety JA. Phytochemical Studies on Medicinal Plants, Dracaenaceae resin, of Socotra Island, Yemen. PSM Biological Res. 2016; 1(2): 62-5. doi: 10.1016/j.fitote.2005.02.009.

18. Fengqin W, JIANG $K$, Zuguang L. Purification and identification of genistein in Ginkgo biloba leaf extract. Chin. J. Chromatogr. 2007; 25(4): 509-13. doi: 10.1016/S18722059(07)60019-4.

19. Sato S, Hiroe K, Kumazawa $T$ and Jun-Ichi O. Total synthesis of two isoflavone Cglycosides: genistein and orobol 8 -C- $\beta$-Dglucopyranosides. Carbohydr Res. 2006; 341(9): 1091-5. doi: 10.1055/s-0030-1257859.

20. Afifi FU, Kasabri V, Litescu S, Abaza IF and Tawaha K. Phytochemical and Biological Evaluations of Arum hygrophilum Boiss.
(Araceae). Pharmacogn. Mag. 2017 Apr-Jun; 13(50): 275-80. doi: 10.4103/0973-1296. 204551.

21. Cole C, Burgoyne T, Lee A, Stehno-Bittel L and Zaid G. Erratum to: Arum Palaestinum with isovanillin, linolenic acid and beta-sitosterol inhibits prostate cancer spheroids and reduces the growth rate of prostate tumors in mice. BMC Complement. Altern. Med. 2015 Sep. 14; 15: 322. doi: 10.1186/s12906-015-0854-6.

22. Husein AI, Ali-Shtayeh MS, Jondi WJ, Zatar $\mathrm{NA}, \mathrm{Abu}-\mathrm{Reidah} \mathrm{IM}$ and Jamous RM. In vitro antioxidant and antitumor activities of six selected plants used in the traditional Arabic Palestinian herbal medicine. Pharm. Biol. 2014 Oct; 52(10): 1249-55. doi: 10.3109/13880209. 2014.886274.

23. Rensen IV, Veit M, Wray V and Czygan FC. Genistein-C-glucosides from Genista cinerea. Nat. Prod. Lett. 1995; 6(3): 203-7. doi: 10.1080/10575639508043160.

24. King AMY, Young G. Characteristics and occurrence of phenolic phytochemicals. J. Am. Diet. Assoc. 1999; 99(2): 213-8. doi: 10.1016/S0002-8223(99)00051-6.

25. Mackova Z, Koblovska R and Lapcik O. Distribution of isoflavonoids in non-leguminous taxa-an update. Phytochemistry 2006;67(9):84955. doi: 10.1016/j.phytochem.2006.01.020.

26. Rucinska A, Kirko S and Gabryelak T. Effect of the phytoestrogen, genistein-8-C-glucoside, on Chinese hamster ovary cells in vitro. Cell Biol. Int. 2007; 31(11): 1371-8.

27. Hafidh RR. A comprehensive anticancer molecular study for genistein the promising anticancer drug. J. Contemp. Med. Sci. 2017; 3(11): 264-9. doi: 10.1016/j.cellbi.2007.05.012.

28. Yang H, Lee SH, Ji H, Kim JE, Yoo R, Kim JH, Suk S, Huh CS, Park JHY, Heo YS, Shin HS, 
Kim BG and Lee KW. Orobol, an enzymeconvertible product of genistein, exerts antiobesity effects by targeting casein kinase 1 Epsilon. Sci. Rep. 2019; 9(1): 8942. doi: 10.1038/s41598-019-43950-9.
How to cite this article: Tofighi Z, Shahpar Y, Taheri AR, Tavakoli S, Asatouri R, Eftekhari M, Vazirian M, Shams Ardekani MR, Sadati lamardi SN. Identification of isoflavonoids in antioxidant effective fraction of Arum rupicola Boiss. leaves. Journal of Medicinal Plants 2021; 20(79): 14-23.

doi: $10.52547 / j m p .20 .79 .14$ 


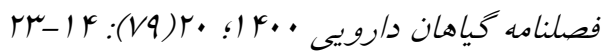

فصلنامه گياهان دارويى

مقاله تحقيقاتى

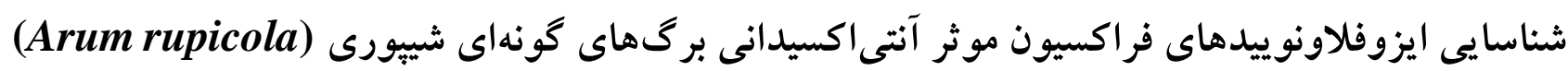

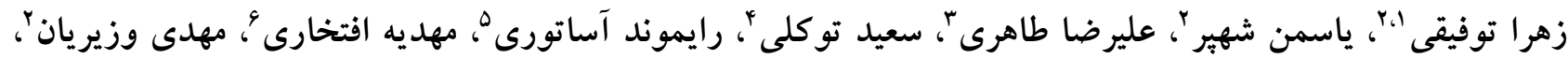

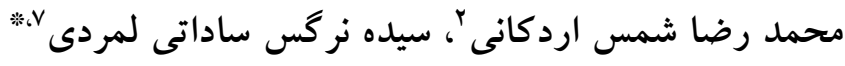

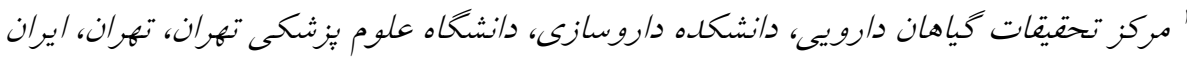

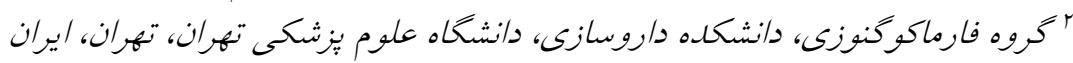

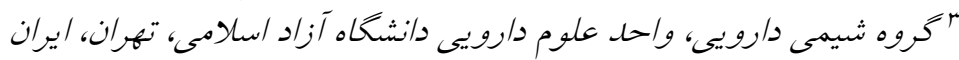

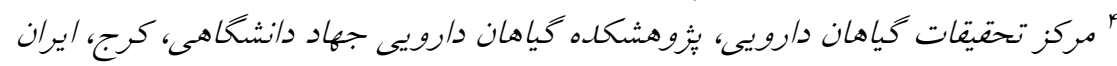

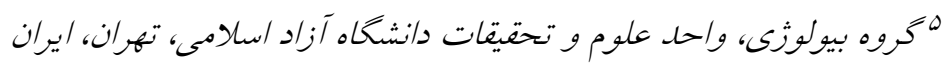

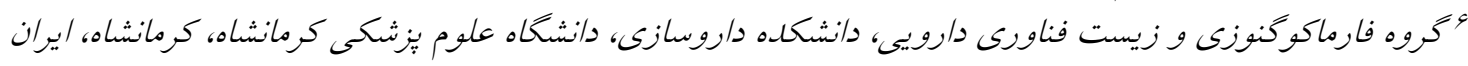

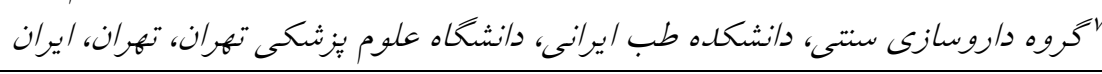

\begin{tabular}{|c|c|}
\hline جִكيده & مقاله \\
\hline 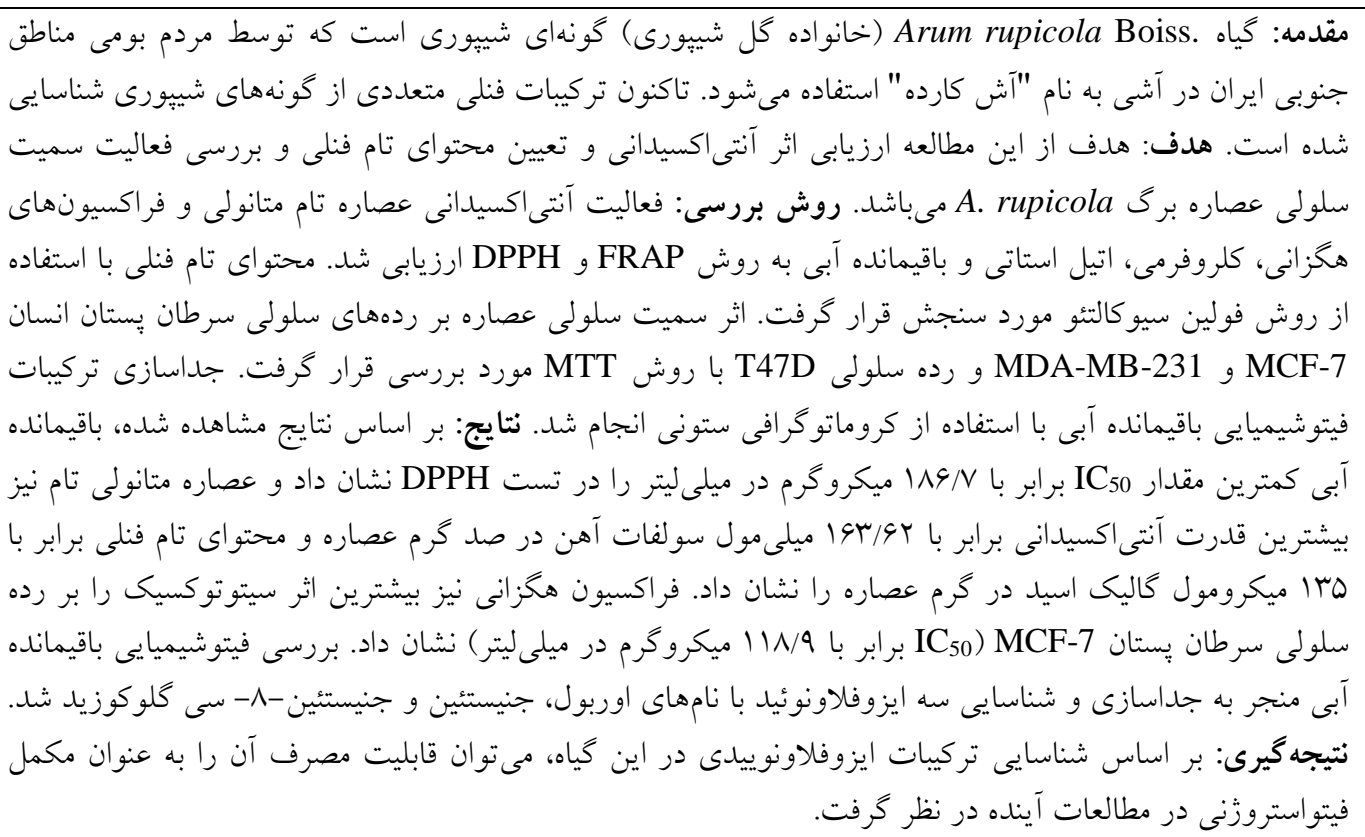 & 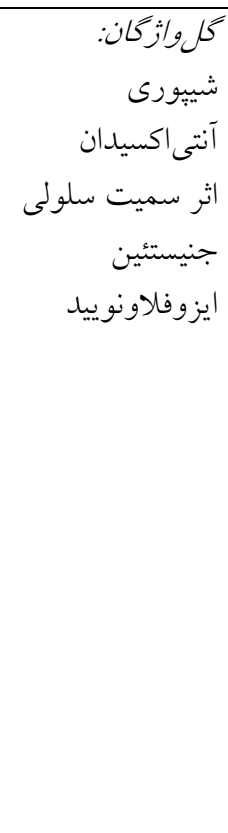 \\
\hline
\end{tabular}

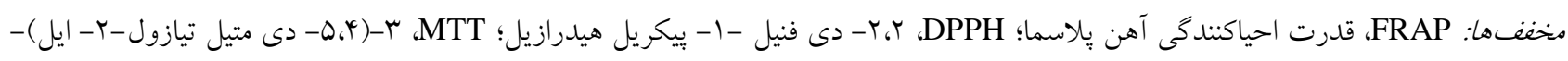

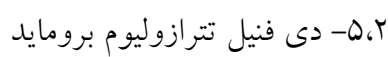

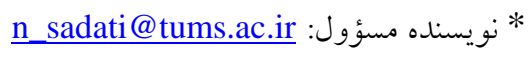
doi: $10.52547 /$ jmp.20.79.14

(C) 2020. Open access. This article is distributed under the terms of the Creative Commons Attribution-NonCommercial 4.0 International License (https://creativecommons.org/licenses/by-nc/4.0/) 